\title{
Foreign Aid Contribution for the Development of Nepal
}

\author{
Anjay Kumar Mishra*, \& P. S. Aithal** \\ *Post Doctoral Research Scholar, Srinivas University, India and Associate Professor, Madan \\ Bhandari Memorial Academy Nepal, Urlabari3, Morang, Nepal \\ OrcidID: 0000-0003-2803-4918; Email: anjaymishra2000@gmail.com \\ ***Professor, College of Management \& Commerce, Srinivas University, Mangalore, India \\ OrcidID: 0000-0002-4691-8736; E-mail: psaithal@gmail.com
}

Area/Section: Business Management.

Type of the Paper: Review Paper.

Type of Review: Peer Reviewed as per $|\mathrm{C}| \mathrm{O}|\mathrm{P}| \mathrm{E} \mid$ guidance.

Indexed in: OpenAIRE.

DOI: https://doi.org/10.5281

Google Scholar Citation: IJMTS

\section{How to Cite this Paper:}

Mishra, Anjay Kumar, \& Aithal, P. S., (2021). Foreign Aid Contribution for the Development of Nepal. International Journal of Management, Technology, and Social Sciences (IJMTS), 6(1), 162-169. DOI: https://doi.org/10.5281

International Journal of Management, Technology, and Social Sciences (IJMTS)

A Refereed International Journal of Srinivas University, India.

CrossRef DOI: https://doi.org/10.47992/IJMTS.2581.6012.0136

(C) With Author.

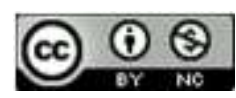

This work is licensed under a Creative Commons Attribution-Non-Commercial 4.0 International License subject to proper citation to the publication source of the work.

Disclaimer: The scholarly papers as reviewed and published by the Srinivas Publications (S.P.), India are the views and opinions of their respective authors and are not the views or opinions of the SP. The SP disclaims of any harm or loss caused due to the published content to any party. 


\title{
Foreign Aid Contribution for the Development of Nepal
}

\author{
Anjay Kumar Mishra*, \& P. S. Aithal** \\ *Post Doctoral Research Scholar, Srinivas University, India and Associate Professor, Madan \\ Bhandari Memorial Academy Nepal, Urlabari3, Morang, Nepal \\ OrcidID: 0000-0003-2803-4918; Email: anjaymishra2000@gmail.com \\ **Professor, College of Management \& Commerce, Srinivas University, Mangalore, India \\ OrcidID: 0000-0002-4691-8736; E-mail: psaithal@gmail.com
}

\begin{abstract}
Purpose: Nepal is small and buetiful country with a great deficiency in infrastructure development. Foreign aid is believed as key component for development in Nepal. The Paper aims to assess foreign aid contribution for developing Nepal.

Design/Methodology/Approach: The study is based on secondary data from 2001/02 to 2014/15 with special reference to Swiss aid. The correlation and regression with normality test have been applied to conform the contributory association among GDP, Swiss Aid and total Aid.

Findings/Result: The real GDP and Aid are highly associated. The regression line is well fit and explained that 85 percent real GDP depends on Swiss aid and the remaining 14 percent other variables. The coefficient of LNTAD is 0.35 and it shows that one percent increase in the total aid increases real GDP by 0.35 percent. The coefficient of LNTAD is positive and significant, meaning that the increase in the total aid increases economic growth in Nepal. By using Brush- Godfery LM test, the $\mathrm{P}$ value is more than 5 five percent, which is 32 percent indicates that there is no autocorrelation among the error terms.
\end{abstract}

Originality/Value: It is an empirical research to signify the contribution of aid for development of Nepal using inferential model.

Paper Type: Analytical Policy Research

Keywords: GDP, LNTAD, Growth, Dependency, Total Aid

\section{INTRODUCTION :}

Nepalese economy is moving around the vicious circle of poverty. To break this type of circle the country needs to raise the income level of people engaged in development which require capital and technical investment. In the first stage of development, the aid is the only source for every country to supply the essential equipment such as machineries, fertilizer and other components to achieve the development goal.

Nepal being a least development country is getting aids from different countries and organization in the form of bilateral and multilateral assistance. But when we study the aid inflow in Nepal, it seems to be controversial that the disbursement of the foreign aid has been increasing with increase in expenditure at the same time. This may happen due to inefficiency of administration, non-availability of suitable contractors, resulting delays in the implementation, of projects, lack of the government stability, lack of proper implementation weak bureaucracy system.

Though the proper implementation of foreign aid in Nepal it is still a matter of question, the government of Switzerland has continued to make its investment in and assistance to Nepal since 1948. The Swiss aid is gradually increasing in Nepal and converging major development parts of Nepal by providing grants as well technical support. So, the researcher is trying to assess the contribution of aid in economic development of Nepal with special reference SWISS aid [1].

\section{OBJECTIVES :}

The general objective of the study is to assess the contribution of foreign aids for the development of Nepal. 


\section{LITERATURE REVIEW :}

This study shows the empirical relationship between SWISS aid real GDP and total aid in Nepal. Various empirical tests are used under study. The previous study only explained descriptive analysis of total aid but absence of study SWISS aid and total as well real GDP of Nepal.

\subsection{Size and Growth Rates of Real GDP in Nepal:}

Size and growth rate of real GDP measure the performance of economy. If real growth of GDP are high and sustainable, then it can be said that the economy is performing well. It means higher the real GDP indicates optimum use of available resources in an economy. The real growth rate of GDP depends real GDP. The real GDP of Nepalese economy has been increasing. However, real GDP growth rate is volatile. It means, growth rate Nepalese is ups and down during the study period. Although the size of real GDP is continuously increasing from 2001 onwards, the increment is highly varied. If size of real GDP is increased but real more amounts, the growth rates of real GDP would be high. The growth rate of real GDP is highly varied for the study period. In the fiscal year GDP growth rates of real GDP are highly varied for the study period. In the fiscal years 2001 and 2016 the growth rates of real GDP were lowest. The possible low growth rates during 2001 were Maoist people war and Disaster Earth Quick (25, April 2015) [2] and problems of undeclared blocked by India. In these fiscal years real GDP growth rate were 0.11 percent and 0.55 percent respectively. The highest growth rates observed in 2008 which was positive impact of peace between government and Mao of Nepal as well as election of Constitutional Assembly it was 6.1 percent. Real GDP growth rates are low and unstable in the study period and average growth rate of real GDP was 3.7 for whole study period. (Table 1)

Table 1 : Size and growth Rates of Real GDP

\begin{tabular}{|l|l|l|l|l|l|}
\hline YEAR & $\begin{array}{l}\text { Nominal } \\
\text { GDP }\end{array}$ & $\begin{array}{l}\text { GDP } \\
\text { deflator }\end{array}$ & $\begin{array}{l}\text { GDP } \\
\text { deflator }\end{array}$ & Real GDP & $\begin{array}{l}\text { REAL } \\
\text { GROWTHRATE }\end{array}$ \\
\hline 2000 & 441519 & 100 & 100 & 441519 & - \\
\hline 2001 & 459443 & 103.94 & 103.94 & 442027.1 & 0.11508 \\
\hline 2002 & 492231 & 107.13 & 107.13 & 459470.7 & 3.946274 \\
\hline 2003 & 536749 & 111.6 & 111.6 & 480957.9 & 4.676511 \\
\hline 2004 & 589412 & 118.86 & 118.86 & 495887.6 & 3.104159 \\
\hline 2005 & 654084 & 126.18 & 126.18 & 518373.8 & 4.534536 \\
\hline 2006 & 727827 & 135.38 & 135.38 & 537617.8 & 3.712379 \\
\hline 2007 & 815658 & 142.94 & 142.94 & 570629.6 & 6.140384 \\
\hline 2008 & 988272 & 165.77 & 165.77 & 596170.6 & 4.475933 \\
\hline 2009 & 1193679 & 189.56 & 189.56 & 629710.4 & 5.625873 \\
\hline 2010 & 1366954 & 211.65 & 211.65 & 645855.9 & 2.563956 \\
\hline 2011 & 1527344 & 224.13 & 224.13 & 681454.5 & 5.511849 \\
\hline 2012 & 1695011 & 237.77 & 237.77 & 712878.4 & 4.611298 \\
\hline 2013 & 1941624 & 257.5 & 257.5 & 754028.7 & 5.772415 \\
\hline 2014 & 2161175 & 272.13 & 272.13 & 794170.1 & 5.32359 \\
\hline
\end{tabular}

Source: National Accounts of Nepal (2000-2007), (2012/13) and (2016/17), Central Bureau of Statistics, National Planning Secretariat, Government of Nepal, Ram Shah Path, Kathmandu, Nepal [3],[4],[5].

\section{RESEARCH METHODOLOGY:}

The data have been collected from the publications of finance Minstar, Embassy of Switzerland, Central Bureau of Statistics World Bank, Swiss Agency for development and Co-operation (SDC), UNDP, NRB as secondary sources. The study period is taken from fiscal year 2001/02 to 2014/15 based on availability of data. 
For the analysis of data quantitative as well as qualitative methods are used. However, quantitative techniques have been employed widely. The relationship among GDP, Swiss aid and total aid has been conformed using the correlation and regression along with normality test.

\section{RESULTS AND DISCUSSION :}

\subsection{The Association between real GDP, Swiss Aid and total Aid:}

Association is expressed through Correlation as shown in Table 2. The values of correlation coefficient lie between +1 to -1 . Near to positive 1 indicates higher degree positive association. Similarly, -1 indicates higher degree of negative association between the variables. Near to zero indicates less association between the variables [6].

Table 2 : Association between Real GDP Total Aid and Swiss Aid

\begin{tabular}{|l|c|c|}
\hline & Real GDP & Swiss Aid \\
\hline Real GDP & 1 & 0.9265 \\
\hline Swiss Aid & 0.9265 & 1 \\
\hline
\end{tabular}

\begin{tabular}{|l|c|c|}
\hline & Real GDP & Total Aid \\
\hline Real GDP & 1 & 0.228 \\
\hline Total Aid & 0.228 & 1 \\
\hline
\end{tabular}

The correlation coefficient between real GDP and Swiss Aid 0.9265 which is higher degree association between two variables. The correlation coefficient between the imports and remittances is very high degree. Similarly, the correlation coefficient real GDP and total aid is 0.228 which positive and indicates that there is positive association between total aid and real GDP. This is found in claim of swiss commitments as well [7].

\subsection{Regression analysis between real GDP and Swiss Aid:}

In order to find the magnitude of relationship between Swiss Aid and economic growth, it is necessary to run the OLS regression with economic growth dependent (LNRGDP) variable and Swiss Aid (LNSWD) independent variable.

Table 3 : Regression Analysis real GDP and Swiss Aid

\begin{tabular}{|l|l|l|l|l|}
\hline Variables & Coefficient & $\begin{array}{l}\text { Standard error of } \\
\text { parameters }\end{array}$ & t- statistics & P - value \\
\hline Constant & 11.17361 & 0.190542 & 58.64107 & 0.0000 \\
\hline LNSWD & 0.282126 & 0.025975 & 10.86156 & 0.0000 \\
\hline $\begin{array}{l}R^{2}=0.891 \\
\text { Adjusted } R^{2}=\end{array}$ & DW $=2.008087$ & $\mathrm{~F}=117.9736$ & $\begin{array}{l}\text { Probability of F statistics }= \\
(0.000)^{*}\end{array}$ & $\mathrm{~N}=14$ \\
\hline
\end{tabular}

The coefficient of Swiss aid is 0.2821 and its probability value is less than one percent indicates that it is significant as of table 3 . The value of R-squared is 0.858 which indicates the regression line is well fit and explained that 85 percent real GDP depends on Swiss aid and remaining 14 percent other variables. The value of $\mathrm{F}$ test $\mathrm{P}$ value is less than one percent indicates that the regression line is well fit. The coefficient 0.2821 means one percent increase Swiss aid causes increase in real GDP of Nepal 
by 0.2821 percent while keeping other constant. The value of DW test is near to two which indicate there is no autocorrelation among the error terms. This is also indicated by Breusch- Godfery Serial Correlation LM test. The value of LM test is 0.18 percent which is more than five percent which indicate that there is no autocorrelation among the error terms. Similarly, Heteroskedasticity test by using BrushPagan- Godfery test that variance of error terms are constant. The value observed $R$ squared $p$ value Chi- Squared is more than 5 five percent which is 80 percent. The field illustration by swiss project also supports the same [8].

\subsection{Regression Analysis between Total Aid and Real GDP:}

In order to find the magnitude of relationship between total aid and economic growth, it is necessary to run the OLS regression with economic growth dependent (LNRGDP) variable and total aid (LNTAD) independent variable.

Table 4 : Regression Results LNRGDP as Dependent Variable

\begin{tabular}{|l|l|l|l|l|}
\hline Variables & Coefficient & $\begin{array}{l}\text { Standard error of } \\
\text { parameters }\end{array}$ & t- statistics & P - value \\
\hline Constant & 9.603047 & 0.366352 & 26.21264 & 0.0000 \\
\hline LNTAD & 0.355412 & 0.035798 & 9.928249 & 0.0000 \\
\hline $\begin{array}{l}R^{2}=0.891 \\
\text { Adjusted } R^{2}=\end{array}$ & $\begin{array}{l}\text { DW }=1.78 \\
\text { Adjusted Lag 2 }\end{array}$ & $\mathrm{F}=98.57013$ & $\begin{array}{l}\text { Probability of F statistics }= \\
(0.000)^{*}\end{array}$ & $\mathrm{~N}=14$ \\
\hline
\end{tabular}

The variable LNTAD along with constant term are statistically significant at one percent level. The adjusted coefficient of determination $\left(A d j . R^{2}\right)$ is 0.89 and it shows that the model is best fit. This means dependent variable economic growth can be explained by explained variable total trade 89 percent. The F-statistics, which shows the overall fitness of the model, is statistically significant at one percent level of significance. The same results are found to be illustrated on SWISS claims [9].

The coefficient of LNTAD is 0.35 and it shows that one percent increase in the total aid causes increases real GDP by 0.35 percent. The coefficient of LNTAD is positive and significant, meaning that increase in the total aid increases economic growth in Nepal. By using Brush- Godfery LM test, the P value is more than 5 five percent which is 32 percent indicates that there is no autocorrelation among the error terms.

The positive and significant coefficient conforms that total aid causes the economic growth to rise as theoretically verified based on world banks reports also [10].

\subsection{Normality Test Error terms between Total Aid and Real GDP:}

Normality test of error terms between total aid and real GDP are test by JB. The JB test P value is more than 5 percent which is 76 percent indicates that errors terms are normally distributed as shown in fig 1. 


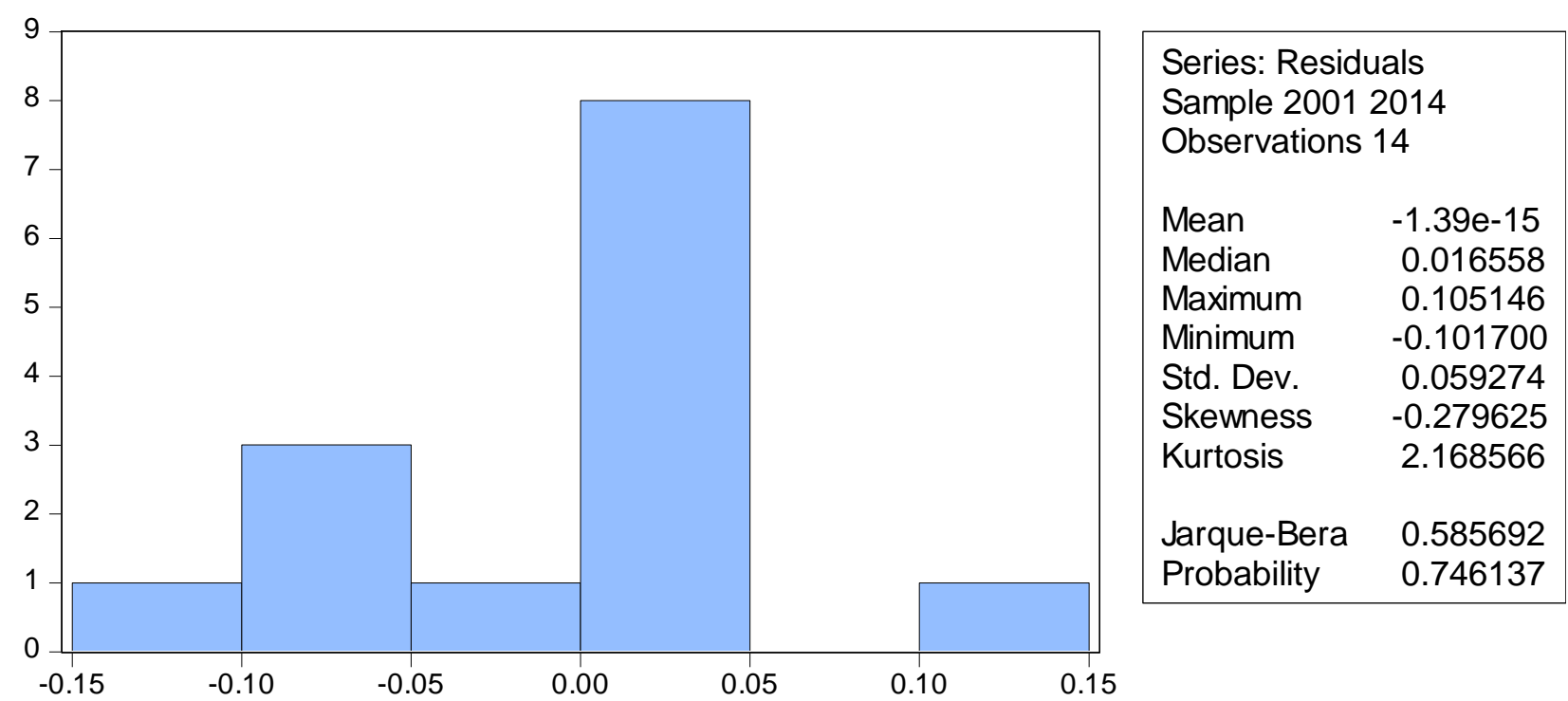

Fig. 1 : Normality Test between Total Aid and Real GDP

\subsection{Normality test error terms between Swiss aid and Real GDP:}

Normality test of error terms between Swiss aid and real GDP are test by JB. The JB test P value is more than 5 percent which is 40 percent indicates that errors terms are normally distributed as shown in fig 2 ..

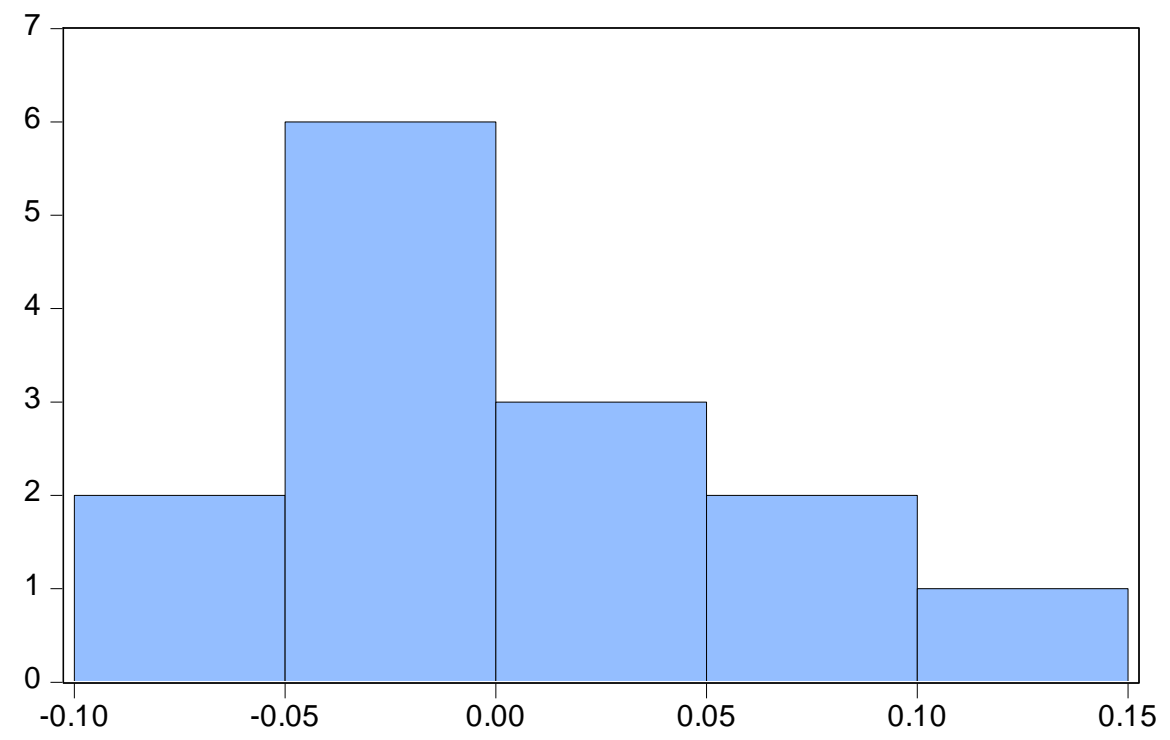

\begin{tabular}{ll}
\multicolumn{3}{l}{ Series: Residuals } \\
Sample 2001 2014 \\
Observations 14 \\
Mean & $-2.92 \mathrm{e}-15$ \\
Median & -0.011813 \\
Maximum & 0.127407 \\
Minimum & -0.076416 \\
Std. Dev. & 0.054671 \\
Skewness & 0.872429 \\
Kurtosis & 3.234003 \\
& \\
Jarque-Bera & 1.807919 \\
Probability & 0.404963 \\
\hline
\end{tabular}

Fig. 2 : Normality Test between Swiss Aid and Real GDP

\section{CONCLUSION :}

The study of the foreign aid provides a clear-cut idea about aid being given by foreign countries for various development works. Switzerland is a highly developed country and stratification in the significant place having higher level of per capital GNI in the world and plays the vital role in the development of countries like Nepal. The correlation coefficient between real GDP and Swiss Aid 0.9265 which is higher degree association between two variables. The correlation coefficient between the imports and remittances is very high degree. Similarly, the correlation coefficient real GDP and total aid is 0.228 which positive and indicates that there is positive association between total aid and real GDP. The coefficient of Swiss aid is 0.2821 and its probability value is less than one percent indicates that it is significant. The value of R-squared is 0.858 which indicates the regression line is well fit and explained that 85 percent real GDP depends on Swiss aid and remaining 14 percent other variables. The value of $\mathrm{F}$ test $\mathrm{P}$ value is less than one percent indicates that the regression line is well 
fit. The coefficient 0.2821 means one percent increase Swiss aid causes increase in real GDP of Nepal by 0.2821 percent while keeping other constant. The value of DW test is near to two which indicate there is no autocorrelation among the error terms. This is also indicated by Breusch- Godfery Serial Correlation LM test. The value of LM test is 0.18 percent which is more than five percent which indicate that there is no autocorrelation among the error terms. Similarly, Heteroskedasticity test by using BrushPagan- Godfery test that variance of error terms are constant. The value observed $R$ squared $p$ value Chi- Squared is more than 5 five percent which is 80 percent.

The variable LNTAD along with constant term are statistically significant at one percent level. The adjusted coefficient of determination $\left(A d j . R^{2}\right)$ is 0.89 and it shows that the model is best fit. This means dependent variable economic growth can be explained by explained variable total aid 89 percent. The F-statistics, which shows the overall fitness of the model, is statistically significant at one percent level of significance.

The coefficient of LNTAD is 0.35 and it shows that one percent increase in the total aid causes increases real GDP by 0.35 percent. The coefficient of LNTAD is positive and significant, meaning that increase in the total aid increases economic growth in Nepal. By using Brush- Godfery LM test, the P value is more than 5 five percent which is 32 percent indicates that there is no autocorrelation among the error terms.

\section{RECOMMENDATIONS :}

Swiss aid is flowing to a variety of sectors of Nepalese economy. Nepalese government should prepare priority projects and request the donor to finance in these projects. While receiving aid priority should be given to these countries that provide maximum grant the technical assistance and do not place fiscal burden on the economy. Aid from European Union and bilateral aid should be given maximum priority. In recent trend multilateral aid is increasing in the economy. Multilateral loans are increasing in Financial Sector reform. Financial sector reform is found very costly but cannot achieve its target. So, government should be aware about unnecessary terms and conditions while receiving. High level aid steering committee should be development in order to due foreign assistance effectively and productively. Politicians, some economists and development planners must change their mentality of grab anything what is available from external sources. While receiving aid politicians must consider the sovereignty of nation can actually the effect of received aid. Swiss aid should be given high priority while receiving foreign aid in Nepal. The areas of Swiss aid inflow should be increased by requesting Swiss government and individuals. Swiss aid should increase in such a way that it covers all remote districts in our country. At preset most of the aid comes with some conditions. Therefore, the conditions should be properly studied and then only those projects which are favorable for the country should be selected. So bargaining capacity must be increased to take foreign aid more favorable. Development plans are heavily relied on foreign aids, form plan to tenth plan more than $55 \%$ development budget is met with foreign aid. So foreign aid should be reduced and internal resources should be mobilized. The heavy difference between total foreign aid commitment and disbursement indicates low absorptive of our country. So, government should increase absorptive capacity.

\section{REFERENCES :}

[1] Mishra, A. K., \& Aithal, P. S., (2021). Foreign Aid Movements in Nepal. International Journal of Management, Technology, and Social Sciences (IJMTS), 6(1), 142-161. DOI: https://doi.org/10.5281/zenodo.4677825.

[2] Mishra A. K. (2019). Development of Building Bye-Laws in Nepal. J Adv Res Const Urban Arch, 4(3\&4), 17-29. https://doi.org/10.24321/2456.9925.201904.

[3] Ministry of Finance (1990/091) to 2014/15), Economic Survey, Kathmandu: MOF assessed from www.aims.mof.gov.np

[4] Ministry of Finance (2019). Foreign Aid Policy of Nepal 2019 Kathmandu: MOF assessed from www.mof.gov.np 
[5] National Planning Commission (First to thirteenth Plan). Kathmandu: NRB from www.nrb.org.np and www.npc.gov.np

[6] Mishra A. K. and Mallik K., (2017). Factors and impact of risk management practice on success of construction projects of housing developers, Kathmandu, Nepal. International Journal of Sciences: Basic and Applied Research (IJSBAR). 36 (7), 206-232.

[7] Swiss Agency for Development cooperation (1993). Country Program For Nepal1993-94. Ekantakuna:

$S A D C$.

https://www.eda.admin.ch/countries/nepal/en/home/representations/embassy-kathmandu/ embassy-tasks/cooperation-office.html

[8] Swiss Agency for Development Corporation (1997). Country Program for Nepal 1998-2004. Ekantakuna:SADC. https://www.eda.admin.ch/countries/nepal/en/home/representations/embassykathmandu/embassy-tasks/cooperation-office.html

[9] Swiss Agency for Development Corporation (2005). Country Program for Nepal 1998-2004. Ekantakuna: SADC. https://www.eda.admin.ch/countries/nepal/en/home/representations/ embassy-kathmandu/embassy-tasks/cooperation-office.html

[10] WB (2005). World Development Report. Kathmandu: WB. https://documents.worldbank.org/en/publication/documentsreports/documentdetail/554071468182337250/world-development-report-2005-a-betterinvestment-climate-for-everyone 